2002

\title{
The Bishops and the Corporate Stakeholder Debate
}

Stephen M. Bainbridge

Follow this and additional works at: https://digitalcommons.law.villanova.edu/vjlim

Part of the Banking and Finance Law Commons, and the Secured Transactions Commons

\section{Recommended Citation}

Stephen M. Bainbridge, The Bishops and the Corporate Stakeholder Debate, 4 Vill. J.L. \& Investment. Mgmt. 3 (2002).

Available at: https://digitalcommons.law.villanova.edu/vjlim/vol4/iss1/2

This Symposia is brought to you for free and open access by Villanova University Charles Widger School of Law Digital Repository. It has been accepted for inclusion in Villanova Journal of Law and Investment Management by an authorized editor of Villanova University Charles Widger School of Law Digital Repository. 


\section{THE BISHOPS AND THE CORPORATE STAKEHOLDER DEBATE}

\section{Stephen M. Bainbridge*}

Should directors of public corporations take into account the interests of corporate constituencies other than shareholders when making decisions? More to the point, at least for purposes of this conference, should faith-based investors encourage directors so to do? ${ }^{1}$ These questions, of course, are a subset of the broader corporate social responsibility debate.

The broader debate asks whether shareholder wealth maximization should be the guiding principle of corporate governance or whether internal corporate decisionmaking processes should include consideration of various social issues. The narrower debate at issue here focuses on the corporation's responsibility to so-called stakeholders: nonshareholder corporate constituents, such as employees, customers, suppliers, and local communities in which the corporation does business. ${ }^{2}$ On one side are those who argue that corporate actions affect not only shareholders, but also a variety of nonshareholder constituencies having legitimate claims on the corporation. Employees, customers, creditors, suppliers, and the communities in which the firm does business all have a stake in the corporate enterprise and are entitled to have their interests considered. ${ }^{3}$ On the other side are those who argue for the primacy of shareholder interests. ${ }^{4}$ Those in this camp argue, as Milton Friedman famously put it, that "the social responsibility of business is to increase its profits." 5

* Professor, UCLA SCHOOL OF LAW. I thank Samuel Gregg for his comments, as well as my fellow panelists, Robert Kennedy and Margaret Blair. The usual disclaimers apply, of course. (C) 2002 Stephen M. Bainbridge.

${ }^{1}$ Leading spokesmen for values-based investing routinely emphasize concern for nonshareholder constituents in connection with both investment and corporate governance decisions. See, e.g., AMY DOMINI, SOCIALLY RESPONSIBLE INVESTING: MAKING A DIFFERENCE AND MAKING MONEY 66 (2001) (noting the need for "stakeholder impact data" in making investment decisions); HAL BRILL ET AL., INVESTING WITH YOUR VALUES: MAKING MONEY AND MAKING A DIFFERENCE 89-91 (2d ed. 2000) (identifying investment screens with strong emphasis on stakeholders).

2 The term "stakeholders" reportedly originated in a 1963 Stanford Research Institute memorandum as a descriptive term for "those groups without whose support the organization would cease to exist." R. Edward Freeman $\&$ David L. Reed, Stockholders and Stakeholders: A New Perspective on Corporate Governance, 25 CAL. MGMT. REV. 88, 89 (1983).

${ }^{3}$ See infra Part I (describing the relevant Catholic social teaching).

${ }^{4}$ See infra notes 34-35 and accompanying text (quoting and discussing Dodge v. Ford Motor Co., 170 N.W. 668 (Mich. 1919)). In this essay, the term "shareholder primacy" is used synonymously with the so-called "shareholder wealth maximization norm." Under either name, the principle requires boards of directors to focus on shareholder wealth maximization when making corporate decisions. See id. In recent years, some scholars have expanded the concept of shareholder primacy to include not only the proposition that shareholders are the principals on whose behalf corporate governance is organized, but also the claim that shareholders do (and should) exercise ultimate control of the corporate enterprise. See, e.g., Henry Hansmann \& Reinier Kraakman, The End of History for Corporate Law, 89 GEO. L.J. 439, 440-41 (2001) (describing the "standard shareholder-oriented" model). As used in this essay, however, the term "shareholder primacy" does not encompass this broader conception. For a critique of the shareholder primacy norm, as more broadly defined by Hansmann and Kraakman (among others), see Stephen M. Bainbridge, Director Primacy: The Means and Ends of Corporate Governance, Nw. U. L. RV. (forthcoming 2003).

${ }^{5}$ Milton Friedman, The Social Responsibility of Business is to Increase its Profits, N.Y. TIMES MAGAZINE, Sept. 13, 1970 , at 32. 
Catholic social teaching on work and capitalism offers a provocative statement of natural law principles with considerable relevance to the stakeholder debate. It therefore serves as my principal foil herein, albeit without intending thereby to denigrate or exclude other religious traditions. ${ }^{6}$ In particular, I devote considerable attention to the moral and ethical claims advanced by the U.S. Catholic Bishops in their controversial pastoral letter on economic justice. ${ }^{7}$

As a relatively recent convert to Catholicism, it is with some trepidation that I take issue with certain aspects of the social teaching. ${ }^{8}$ As with all of the Church's ordinary teaching, the faithful "are to adhere to [the social teaching] with religious asset." ${ }^{\text {Y }}$ et the church encourages lay initiative "especially when the matter involves discovering or inventing the means for permeating social, political, and economic realities with the demands of Christian doctrine and life." ${ }^{10}$ Moreover, an active and critical role for the laity seems especially important with respect to economic life. Michael Novak asserts that Christian theologians tend to be poorly trained in

${ }^{6}$ Cf. Michael NOVAK, CATHOlic SOCtal. THOUght \& IBBERAL INSTITUTIONS: FrEEDOM WiTH JUSTTCE xxiii (2d ed. 2000) (stating that "all who are concerned with the moral and religious quality of human systems should find [the Catholic social] tradition both instructive in itself and parallel to developments in their own intellectual histories").

7 NATIONAL CONFERENCE OF CATHOLIC BISHOPS, ECONOMIC JUSTICE FOR ALL: PASTORAL LETTER ON CATHOLIC SOCIAL TEACHING AND THE U.S. ECONOMY (1986) [hereinafter BISHOPS LETTER]. A firestorm of criticism surrounded the BISHOPS' LETTER. A relatively diverse and representative spectrum of views, as well as a copy of the letter itself, is contained in THE CATHOLIC CHALLENGE TO THE AMERICAN ECONOMY: REFLECTIONS ON THE U.S. Bishops' PASTORAL LETTER ON CATHOLIC SOCIAL TEACHING AND THE U.S. ECONOMY (Thomas M. Gannon ed., 1987).

${ }^{8}$ I trust this concern will not seem misplaced at a conference on faith-based investing, even though I realize that many academics will find it eccentric, at best. As Thomas Shaffer pointedly observed, modern law schools "have systematically - theologically! - discounted, discouraged and disapproved of the invocation of the religious tradition as important, or even interesting." Thomas Shaffer, The Tension Between Law in America and the Religious Tradition, in THE WEIGHTIER MATTERS OF THE LAW: ESSAYS ON LAW AND RELIGION 315, 327 (John Witte \& Frank Alexander eds., 1988).

${ }^{9}$ UNited StATES CATHOLIC CONFERENCE, CATECHISM OF THE CATHOLIC CHURCH $\uparrow 892$ (2d ed. 1997) [hereinafter CATECHISM].

${ }^{10}$ Id. at 899. Villanova Law School Dean Mark Sargent observes that "the Catholic university-and hence, the Catholic law school-is where the Church does its thinking." Mark A. Sargent, An Alternative to the Sectarian Vision: The Role of the Dean in an Inclusive Catholic Law School, 33 U. TOLEDO L. REV. 171, 181 (2001). In my view, one properly may generalize Sargent's proposition to the believing laity as a whole. Hence, it is the task of Catholic intellectuals to exercise critical reflective judgment with respect to society, the Church, and the relationship between the two. On the other hand, I recognize that there is a fine line between the exercise of critical evaluative judgment and dissent. On the legitimacy of dissent from the magisterium of the Church, compare Christopher Wolfe, The Ideal of a (Catholic) Law School, 78 MARQ. L. REV. 487, 497-98 (1995) (arguing there is no "right to dissent" as that term is broadly understood) with Michael J. Perry, The Idea of a Catholic University, $78 \mathrm{MARQ}$. L. REV. 325, 346 (1995) (arguing that "Catholics can and do, without forfeiting our identity as Catholics, dissent from one or another theological proposition"). In the present context, however, there seems no need to resolve this debate. When it comes to issues such as the degree of state intervention in the economy, for example, the Church outlines basic principles but recognizes substantial latitude with respect to their translation into public policy. Nowhere, for example, does the Church state what percentage of the economy should by controlled by the state, thus leaving a great deal of room for prudential judgement by Catholics. In promulgating their pastoral letter, moreover, the Bishops expressly acknowledged that their "prudential judgments" about specific policy recommendations were not made "with the same kind of authority that marks our declarations of principle." BISHOPS" LETTER, supra note 7, at xii. 
economics and inexperienced with the business world. They "are likely to inherit either a precapitalist or a frankly socialist set of ideals about political economy."11 Consequently, theologians "are more likely to err in this territory [i.e., economic justice] than in most others."12

The exercise of critical evaluative judgment seems especially appropriate with respect to the analysis and claims made in the BISHOPS' LETTER. Although Pope John Paul II has cautioned that the Catholic "church has no models to present," 13 the BISHOPS' LETTER claimed to speak not only to Catholics but also to U.S. society at large. ${ }^{14}$ In a very real sense, the BISHOPS' LETTER was not only a theological document, but also a position paper addressed to policymakers. ${ }^{15}$ Consequently, it seems fair to question whether one can find sound social policy in the Bishops' moral and ethical claims.

The Bishops agreed with those who believe that corporate directors should consider the interests of nonshareholder corporate constituents when making business decisions; indeed, they argued that directors are morally obligated to do so. ${ }^{16}$ In this essay, I argue the Bishops' thesis is flawed in two respects. First, the normative arguments they advanced do not justify setting aside corporate law's traditional focus on shareholder wealth maximization. Second, despite the position paper-like nature of the BISHOPS' LETTER, the Bishops failed to grapple with the fundamental problems inherent in giving corporate managers discretion to consider concerns other than shareholder wealth maximization.

To be sure, on its face, the BISHOPS' LETTER merely states a moral norm it did not purport to make specific law reform proposals. Absent law reform, however, the BISHOPS' LETTER presented faithful directors with the difficult moral dilemma of reconciling their moral and legal obligations. When this concern is coupled with the general policy orientation of the BISHOPS' LETTER, it seems fair to treat the Bishops' position as an implicit law reform proposal intended to align the directors' moral and legal duties. Hence, my focus here is on the question of whether the positive law should incorporate the Bishops' understanding of the board's moral role. Unfortunately, the Bishops provide little guidance as to how this might be done-a

\footnotetext{
11 Michael NOVAK, TOWARD A THEOLOGY OF THE CORPORATION 59 (rev. ed. 1990).

${ }^{12} \mathrm{Id}$. at 12 .

${ }^{13}$ John Paul II, Centesimus Annus $\mathbb{9}$ 43, reprinted in PROClAIMING JUSTICE \& PEACE: PAPAL DOCUMENTS FROM RERUM NOVARUM THROUGH CENTESIMUS ANNUS 432, 465 (Michael Walsh \& Brian Davies eds., 1991). Some Catholic intellectuals contend that Centesimus Annus calls into question "the controlling assumptions" of the BISHOPS" LETTER and even that it provides a basis for rejecting the pastoral letter "as unrepresentative of the Church's authoritative teaching." Richard John Neuhaus, An Argument About Human Nature, in A NEW WORLDLY ORDER: JOHN PAUL II AND HUMAN FREEDOM 123, 124 (George Weigel ed., 1992). If this perspective suggests caution in over-emphasizing the BISHOPS' LETTER in an analysis of Catholic social teaching on corporate social responsibility, it also suggests the legitimacy of applying critical evaluative judgment to the specific policy proposals contained therein. See also supra note 10 (discussing the legitimacy of dissent).

${ }^{14}$ See, e.g., BISHOPS LETTER, supra note 7, at -27 (stating that the Bishops desired "to add our voice to the public debate").

${ }^{15}$ See id.

${ }^{16}$ See id. at 1 T 298-306. The Bishops did not impose a comparable moral obligation on shareholders in connection with their decisionmaking capacity. Instead, they called for further research on the relationship of shareholders and nonshareholder constituents. See $i d$. at $\uparrow 306$. Although the question has obvious relevance for faith-based investors, this essay declines the Bishops' invitation.
} 
common failing of Catholic social teaching. ${ }^{17}$ The Church tends to be long on pious exhortations and short on detailed policy prescriptions. The broad amorphous statements of moral norms typical of Catholic social teaching (and much commentary thereon) are a blunt instrument poorly suited to the sort of fine detail work demanded of lawyers, judges, and legislators.

Part I of this essay briefly summarizes the position taken by the BISHOPS' LETTER on the stakeholder debate, placing that position within the context of the broader Catholic social teaching, as well as offering a preliminary critique of the normative underpinnings of the Bishops' position. Part II then evaluates three ways in which the Bishops' position might be translated into public policy: (1) directors could be given nonreviewable discretion to make trade-offs between shareholder and stakeholder interests; (2) directors could be given reviewable discretion to make such trade-offs; or (3) directors could be required to make such trade-offs subject to judicial (or regulatory) oversight. None of these approaches is an improvement on current law; to the contrary, all are worse. The first approach would be toothless, the second would increase agency costs, and the third would either prove unworkable or pose an unwarranted threat to economic liberty (or both).

\section{THE BISHOPS' LETTER AND THE STAKEHOLDER DEBATE}

\section{A. A Brief Note on Methodology}

Are instrumental and consequentialist considerations an appropriate basis on which to critique the Bishops' analysis? In particular, is concern with economic efficiency relevant to that critique ${ }^{18}$ In my judgment, an instrumental analysis can be instructive. Although cost-benefit analysis may strike a discordant note in an essay on Catholic social teaching, concern for efficiency is a legitimate element of the methodology by which that teaching is worked out, analyzed, and critiqued.

The Church's social teaching rests on a foundation of natural law principles. ${ }^{19}$ In turn, natural law consists of "a loosely-knit body of rules of action prescribed by an authority superior

\footnotetext{
17 See Scott Fitzgibbon, "True Human Community": Catholic Social Thought, Aristotelian Ethics, and the Moral Order of the Business Company, 45 ST. LOUIS U.L.J. 1243, 1247-52 (2001) (arguing that Catholic moral treatises are unhelpful in dealing with practical problems of business ethics).

${ }^{18}$ Economic efficiency can be defined in various ways. The Pareto superiority efficiency is satisfied when a change makes at least one person better off and no one worse off. In contrast, Kaldor-Hicks efficiency does not require that no one be made worse off by a reallocation of resources. Instead, it requires only a net social wealth increase, such that the gains to the "winners" exceed the losses incurred by the "losers." Moreover, there is no requirement that the winners compensate the losers. See RICHARD A. POSNER, ECONOMIC ANALYSIS OF LAW 13-14 (4th ed. 1992) (defining efficiency concepts). For purposes of this essay, I accept Kaldor-Hicks as a working definition of economic efficiency. I acknowledge, however, that the ethical validity of Kaldor-Hicks efficiency as a guide to public policy is sharply disputed. Compare RICHARD A. POSNER, THE ECONOMICS OF JUSTICE 91-94 (1981) (defending Kaldor-Hicks) with Bruce Chapman, Trust, Economic Rationality, and the Corporate Fiduciary Obligation, 43 U. Toronto L. Rev. 547, 554-55 (1993) (noting arguments against use of Kaldor-Hicks as a guide to social policymaking).

19 See Angela C. Carmella, A Catholic View of Law and Justice, in CHRISTIAN PERSPECTIVES ON LEGAL THOUGHT 255, 258 (Michael W. McConnell et al. eds., 2001) (noting the "natural-law emphasis in Catholic social thought"); see also MICHAEL NOVAK, THE CATHOLIC ETHIC AND THE SPIRIT OF CAPITALISM 51 (1993) (noting the importance of "natural justice" and "natural rights" in Pope Leo XIII's seminal encyclical on economic justice, Rerum Novarum).
} 
to the state." ${ }^{20}$ But what authority? Russell Kirk explained that the different schools of natural law derive the principles of that law variously from "divine commandment, from right reason with which man is endowed by his Creator, from the nature of mankind empirically regarded, from the abstract Reason of the Enlightenment, or from the long experience of humankind in the community." 21 Among these options, Catholic social teaching draws principally on philosophical reasoning and revealed truth. ${ }^{22}$ The Catholic perspective thus is not inconsistent with Edmund Burke's description of natural law as "eternal enactments of divine authority which we can endeavor to apprehend through the study of history and the observation of human character."23

Central to the intellectual apparatus by which we discern the "eternal enactments of divine authority" is what John Finnis calls the test of practical reasonableness. ${ }^{24}$ Practical reasoning is a way of thinking about how things ought to be, using rational arguments about how people ought to behave. ${ }^{25}$ Or, as Finnis put it, practical reasoning is the natural law method of "working out the (moral) natural law from the first (pre-moral) principles of natural law." ${ }^{26}$ In particular, it is a way of choosing "commitments, projects, and actions, knowing that choice

${ }^{20}$ Russell Kirk, Natural Law and the Constitution of the United States, 69 NOTRE DAME L. REV. 1035, 1036 (1994).
${ }^{21}$ Id.

${ }^{22}$ See Carmella, supra note 19, at 258 (noting that Catholic social thought has "become more expressly biblical and christological" in addition to its traditional emphasis on philosophy). Of course, skeptics deny that the truth of a moral principle can be established. At best, they regard moral norms as indeterminate "can't helps." Yet, the genuine immo rality of an act is a necessary (but not sufficient) condition for the legitimacy of its legal prohibition. See Gerard V. Bradley, Pluralistic Perfectionism: A Review Essay of MAKING MEN MORAL, 71 NOTRE DAME L. REV. 671, 674-75 (1996) (positing that "the immorality of acts is relevant to the legitimacy of their legal prohibition"). Because all conceptions of the good necessarily invoke nonderivable moral assumptions, we cannot avoid an inquiry into the morality of an act we propose to regulate. See Bobby Jindal, Relativism, Neutrality, and Transcendentalism: Beyond Autonomy, 57 LA. L. REV. 1253, 1253 (1997).

${ }^{23}$ RUSSELl KIRK, THE CONSERVATIVE MTND: FROM BURKE TO ELIOT 49 (7th ed. 1993) (paraphrasing Burke on natural rights).

24 See JOHN FINNIS, NATURAL LAW AND NATURAL RIGHTS 100-27 (1980) (defining and describing the test of practical reason). Practical reasonableness is only part of Finnis's jurisprudence of natural law, the totality of which consists mostly of lists. He begins with a list of seven "basic values": life, knowledge, play, aesthetic experience, friendship, practical reasonableness, and religion. Id. at 86-90. In turn, the test of practical reasonableness consists of a list of nine requirements: a coherent plan of life, no arbitrary preferences among value, no arbitrary preferences among persons, detachment, commitment, efficiency, respect for every basic value in every act, the common good, and following one's conscience. See id. at 103-26. Each of the seven basic values are said to be of equal importance; Finnis denies that it is possible to rank them. See id. at 92-93. Instead, an important component of practical reasonableness is making decisions in a way that does not directly damage any of the seven basic values. See id. at 119-20. Because Finnis defines natural law as being concerned with "good and proper conduct," not drafting positive legishation, he is willing to accept the resulting indeterminacy. $I d$. at 18 . Indeed, Finnis acknowledges that "the integration of even an uncontroversial requirement of practical reasonableness into the [positive] law will not be a simple matter." Id. at 284. For criticism of Finnis' reliance on lists, his proposed list of basic values, and his definition of practical reasonableness, see generally William H. Wilcox, Natural Law and Natural Rights, 68 CORNELL L. REV. 408 (1983) (book review).

${ }^{25}$ See Steven J. Burton, Judge Posner's Jurisprudence of Skepticism, 87 MiCH. L. REV. 710,715 (1988) (arguing that "a more complete assimilation of the practical perspective of the legal actor would under cut Judge Posner's argument for legal skepticism").

${ }^{26}$ FINNIS, supra note 24 , at 103 (internal quotation marks omitted). 
effectively rules out many alternative reasonable or possible commitment(s), project(s), and action(s)."27

Finnis, of course, is a leading critic of consequentialist reasoning. ${ }^{28}$ Hence, he presumably would argue that practical reasonableness should not be confused with a purely instrumental approach to natural law. At the same time, however, Finnis concedes that one should seek to achieve the good by actions that are efficient for their purposes. ${ }^{29}$ As he acknowledges, "[o]ne must not waste one's opportunities by using inefficient methods." 30 If even a prominent nonconsequentialist is willing to admit that cost-benefit analysis comes into play when analyzing natural law claims, it seems we may do so with some confidence.

\section{B. The B ishops' Policy Position}

No one seriously denies that corporate conduct generates negative externalities. ${ }^{31}$ Instead, debate tends to focus on two issues. First, what conduct in fact gives rise to externalities about which there should be legitimate concern? Second, and more pertinent to the topic at hand, how should true negative externalities be regulated? The standard welfare economics answer, of course, is to induce the actor to internalize the full social cost of his conduct. ${ }^{32}$ Yet, even setting aside the thorny problem of how to incent corporate actors, ${ }^{33}$ one still must ask whether it makes sense to give corporate directors discretion to consider the effects of their decisions on nonshareholder constituencies.

American corporate law has rejected extending the board's discretionary authority that far. As the Michigan supreme court famously explained in Dodge v. Ford Motor Co.: ${ }^{34}$

${ }^{27} \mathrm{Id}$. at 100 .

${ }^{28}$ See id. at 112 (asserting consequentialist reasoning to be "irrational").

${ }^{29}$ See id. at 111 .

${ }^{30} \mathrm{Id}$. To be sure, Finnis constrains the efficiency criterion by reference to other moral crit eria. See id. at 112 (setting out a list of criteria over and above mere efficiency); $c f$. SAMUEL GREGG, THE ART OF CORPORATE GOVERNANCE 25 (2001) (arguing that it would be "mo rally negligent" to ignore consequences, but also positing that "consideration of consequences is not sufficient for judging" the morality of actions; emphasis in original).

${ }^{31}$ It is for this reason that one cannot justify the shareholder wealth maximization norm by claiming that a rising tide lifts all boats. In many cases, a rising tide will lift affected vessels. Nonshareholder constituencies have a claim on the corporation that is both fixed and prior to that of the shareholders. So long as general welfare laws prohibit the corporation from imposing negative externalities on those constituencies, the shareholder wealth maximization norm redounds to their benefit. In some cases, however, the rising tide argument is inapplicable because it fails to take into account the question of risk. Pursuing shareholder wealth maximization often requires one to make risky decisions, which disadvantages nonshareholder constituencies. The increased return associated with an increase in risk does not benefit nonshareholders, because their claim is fixed, whereas the simultaneous increase in the corporation's riskiness makes it less likely that nonshareholder claims will be satisfied. Hence, the rising tide argument cannot be a complete explanation for the shareholder wealth maximization norm.

32 See, e.g., ROBERT COOTER \& THOMAS ULEN, LAW AND ECONOMICS 39-40 (2d ed. 1997) (asserting the internalization of social costs to be desirable public policy).

${ }^{33}$ The problem is aptly summarized by an aphorism commonly attributed to Edward, First Baron Thurlow: "Did you ever expect a corporation to have a conscience, when it has no soul to be damned, and no body to be kicked?" PENGUIN DICTIONARY OF QUOT ATIONS 398 (1960).

${ }^{34} 170$ N.W. 668 (Mich. 1919). 
A business corporation is organized and carried on primarily for the profit of the stockholders. The powers of the directors are to be employed for that end. The discretion of directors is to be exercised in the choice of means to attain that end and does not extend to a change in the end itself, to the reduction of profits or to the nondistribution of profits among stockholders in order to devote them to other purposes. ${ }^{35}$

At first blush, this legal doctrine ought to strike Christians as unpalatable, if not worse. Is not "the love of money the root of all evils"? ${ }^{36}$ Did not Christ himself tell us that we "cannot serve both God and money?" 37 Does not the Bible repeatedly teach us that there are many things more important than wealth, not least of which is the fear of the Lord? How then can Christians associate themselves with a normative principle explicitly intended to maximize wealth, and whose measurement of wealth includes only those preferences having monetary values? Good questions all. Yet, all admit of affirmative answers. ${ }^{38}$

Consider the Parable of the Talents: A master entrusted assets to three servants. Two invested the assets in productive uses, doubling their value, and were rewarded when the master returned. The third, however, simply returned the master's assets without having earned even interest on them and was punished. ${ }^{39}$ While Christ used this parable to make a theological point, like all of his parables its religious significance depended upon the illustration's secular

\footnotetext{
${ }^{35} \mathrm{Id}$. at 684 . The legal context is complicated by the business judgment rule, which apparently grants directors the discretion to make trade-offs between nonshareholder and shareholder interests. Properly understood, however, the case law does not stand for that proposition. Instead, the cases stand for the proposition that courts will abstain from reviewing the exercise of directorial discretion even when the complainant alleges that directors took nonshareholder interests into account in making their decision. See infra notes 98-106 and accompanying text (discussing the relationship of the business judgment rule to the norm of shareholder wealth maximization); see generally Stephen M. Bainbridge, Interpreting Nonshareholder Constituency Statutes, 19 PEPPERDINE L. RE V. 971 (1992) (same).
}

To be sure, a few cases suggest that directors need not treat shareholder wealth maximization as their sole normative objective. Upon close examination, however, most of these cases are not inconsistent with Dodge. In A.P. Smith Manufacturing Co. v. Barlow, 98 A.2d 581 (N.J. 1953), for example, the New Jersey supreme court validated corporate charitable giving on the ground, inter alia, that "modern conditions require that corporations acknowledge and discharge social as well as private responsibilities as members of the communities within which they operate." $I d$. at 586. The rhetorical difference between Barlow and Dodge, however, has only symbolic import. Shareholders' long-run interests are often served by decisions, such as charitable giving, that appear to be harmful in the short-run. In Barlow, $98 \mathrm{~A} .2 \mathrm{~d}$ at 586, for example, the court recognized that such arguments justified the challenged contribution, arguably rendering its broader language on corporate social responsibility mere dictum.

As for the so-called nonshareholder constituency statutes, which appear to be inconsistent with the traditional view espoused by Dodge and its ilk, see infra note 86 .

${ }^{36} 1$ Timothy 6:10 (NAB).

${ }^{37}$ LUKE 16:13 (NIV).

${ }^{38}$ See generally Stephen M. Bainbridge, Law and Economics: An Apologia, in CHRISTIAN PERSPECTIVES ON LEGAL THOUGHT 208 (Michael W. McConnell et al. eds., 2001) (discussing and defending the economic principle of wealth maximization).

${ }^{39}$ MATTHEW 25:14-30. A somewhat different version of the parable, perhaps taught on a different occasion, appears in LUKE 19:11-27. 
validity. ${ }^{40}$ Here, the parable was (and remains) effective because its hearers already understood the importance of faithfulness and fruitful obedience on the part of stewards.

Catholicism still understands that it is important for faithful stewards to vigorously pursue the profit of their masters. The Catechism explains that profits "make possible the investments that ensure the future of a business and they guarantee employment." 41 Pope John Paul II's encyclical Centesimus Annus likewise recognized a legitimate "role of profit," albeit merely "as an indicator that a business is functioning well." 42

In contrast, the BISHOPS' LETTER requires stewards (here directors) to be faithful to interests other than merely those of their masters (here shareholders). ${ }^{43}$ The Bishops assert that a board of directors' decisions affect a much broader class of constituency groups than merely their shareholders. ${ }^{44}$ Employees, managers, customers, creditors, suppliers, and communities all contribute to the enterprise, all have a stake in its success, and all are affected by its actions. ${ }^{45}$ Hence, their interests must be reflected in the corporate decisionmaking process. To be sure, the Bishops acknowledged the directors' and officers' legal obligation to maximize shareholder wealth. ${ }^{46}$ They argued, however, that "morally this legal responsibility may be exercised only within the bounds of justice to employees, customers, suppliers, and the local community." ${ }^{7}$ In other words, corporate decisionmakers have a moral obligation to balance a decision's impact on stakeholders against its economic impact on shareholders.

The BISHOPS' LETTER, of course, is but one thread in the rich tapestry of Catholic social thought. The most authoritative statements of the social tradition, moreover, are found in the

40 "The parables of Jesus are stories that are true to life" and "are never removed from reality." Rather, "[t]hey are stories taken from the world in which Jesus lived and are told for the purpose of relating a spiritual truth." Simon J. Kistemaker, Parables in EVANGELICAL DiCTIONARY OF THEOLOGY 824 (Walter A. Elwell ed., 1984).

${ }^{41}$ CATECHISM, supra note 9 , at 92432.

${ }^{42}$ Centesimus Annus, supra note 13, at $\$ 43$.

${ }^{43}$ The traditional conception in which directors are stewards of shareholder interests depends upon the corporation being a thing capable of being owned. In the nexus of the contracts model that prevails in the law and economics community, however, shareholders do not own the corporation. Indeed, the corporation is not a thing capable of being owned, but rather simply the nexus of a set of contracts between factors of production. See infra notes 65-66. Hence, the master-servant relationship of the Parable of the Talents is somewhat inapt as an analogy for the relationship of directors and shareholders. As I have argued elsewhere, the corporation is properly viewed as a vehicle by which directors hire factors of production, including equity capital, rather than as a vehicle by which shareholders employ stewards. Indeed, directors are more akin to Platonic guardians than to stewards. See Bainbridge, supra note 4. For an argument that the shareholder wealth maximization norm nevertheless can be squared with the contractarian account, see $i d$.

44 See BISHOPS' LETTER, supra note 7, at $\uparrow 298$.

${ }^{45}$ As examples, the Bishops offer plant closings and corporate takeovers, both of which have substantial affects on those groups. See id. at 9 『 $303,305$.

${ }^{46}$ See id. at $\uparrow 305$.

47 Id. The Bishops also proposed several institutional changes to corporate governance designed to promote stakeholder participation in firm decisionmaking. For example, they urged greater use of worker ownership and worker determinism. Id. at 9 300. They also urged labor unions to explore new relationships with management. Id. at I 304. For a critique of such proposals, see Stephen M. Bainbridge, Corporate Decisionmaking and the Moral Rights of Employees: Participatory Management and Natural Law, 43 VILL. L. REV. 741 (1998). 
series of papal social encyclicals beginning with Pope Leo XIII's Rerum Novarum and including Pope John Paul II's very important post-BISHOPS' LETTER encyclicals Laborem Exercens and Centesimus Annus. ${ }^{48}$ John Paul II's encyclicals temper much of what was said in the BISHOPS' LETTER. ${ }^{49}$ Yet, at least insofar as the present issue is concerned, the BISHOPS' LETTER was not too far out of step with the mainstream of Catholic social thought. As the recently revised Catechism explains, for example: "Those responsible for business enterprises are responsible to society for the economic and ecological effects of their operations. They have an obligation to consider the good of persons and not only the increase of profits." 50

\section{THE B ISHOPS' NORMATIVE ARGUMENT}

The BISHOPS' LETTER posits two principal justifications for the Bishops' position. First, the pastoral letter relies heavily on the principle of economic democracy. Second, the BISHOPS' LETTER relies on a communitarian conception of work and the corporation. In my judgment, neither provides a very convincing policy justification for their position.

1. Economic democracy. According to the Bishops, economic justice requires that all corporate constituents participate in firm decisions. ${ }^{51}$ Consequently, they called for a "new experiment in bringing democratic ideals to economic life." 52 But this attempt to transfer political ideals into the corporation fails both descriptively and prescriptively.

A corporation is not a New England Town meeting. ${ }^{53}$ Rather, it is one of the most hierarchical of our social institutions. ${ }^{54}$ Its sole democratic aspect is the shareholders' right to elect directors and vote on a handful of other decisions. ${ }^{55}$ And, of course, among all corporate constituencies, only shareholders possess even those limited voting rights.

${ }^{48}$ For an extensive history of Catholic social thought as expressed in the relevant series of papal encyclicals and their antecedents, see NOVAK, supra note 6, at 61-164.

${ }^{49}$ See supra note 13.

${ }^{50}$ CATECHISM, supra note 9 , at 92432.

51 See BISHOPS' LETTER, supra note 7, at 9303.

${ }^{52}$ Id. at $\uparrow 298$.

53 See In re TW Services, Inc. Shareholders Litigation, [1989 Transfer Binder] FED. SEC. L. REP. (CCH) 94,334 at 92,180 n.14 (Del. Ch. 1989).

54 See generally ALFRED D. CHANDLER, JR., THE VISIBLE HAND: THE MANAGERIAL REVOLUTION IN AMERICAN BUSINESS 8 (1977) (noting that, over time, corporate hierarchies have proven to possess "a permanence beyond that of any individual or group of individuals who worked in them"); PETER F. DRUCKER, CONCEPT OF THE CORPORATION 141 (rev. ed., Jhn Day Co. 1972) (1946) (contending that "the corporation must be organized on hierarchical lines"); see also infra note 59 and accompanying text (discussing economic benefits to the corporation of hierarchical organization).

${ }^{55}$ Under the Delaware code, for example, shareholder voting rights are essentially limited to the election of directors and approval of charter or bylaw amendments, mergers, sales of substantially all of the corporation's assets, and voluntary dissolution. See MICHAEL P. DOOLEY, FUNDAMENTALS OF CORPORATION LAW 174-77 (1995) (summarizing state corporate law on shareholder voting entitlements). As a formal matter, only the election of directors and amending the bylaws do not require board approval before shareholder action is possible. DEL. CODE ANN. tit. 8, $\S \S 109,211$ (2000). In practice, of course, even the election of directors (absent a proxy contest) is predetermined by the existing board nominating the next year's board. See generally Bayless Manning, Book Review, 67 YALE L.J. 1477, 1485-89 (1958) (describing incumbent control of the proxy voting machinery). 
The absence of economic democracy within the corporation, however, should not be a matter of normative concern. ${ }^{56}$ Democracy is a powerful rhetorical device, and one of which the Bishops make frequent use, but the rhetoric of democracy provides no compelling reason to reject hierarchical decisionmaking in corporations. That we live in a democracy does not require us to convert all of our social institutions into democracies. Democratic societies tolerate a host of hierarchical institutions, not least of which the Catholic Church. Nor does human dignity, another principle invoked by the Bishops, require that all nonshareholder constituents partic ipate in firm decisionmaking. ${ }^{57}$ As I have argued elsewhere in more detail, human dignity and hierarchy are not incompatible. ${ }^{58}$

In fact, hierarchy offers corporations affirmative benefits. ${ }^{59}$ In a sense, management is simply information processing. For effective management, those with the power to make decisions must have the necessary information, which must not be distorted by others' subjective interpretations, but at the same time the decisionmakers must not be overloaded with unnecessary, distracting information. Branching hierarchies put people into small groups, each member of which reports information to the same supervisor. That supervisor is likewise a member of a small group that reports to a superior and so on up to the top. Such an organizational system gets reliable information to the right decisionmaker more efficiently than any other organizational system. Therefore, not surprisingly, some form of branching hierarchy tends to be found in most public corporations: they could not make decisions without it.

2. Communitarianism. As noted above, notions of economic community provide the second normative justification offered on behalf of the Bishops' policy recommendations in this area.

a. The Traditional Ownership-based Theory of the Firm. As the public corporation traditionally was conceived, the firm was not a community but rather a species of private property. Shareholders own the company according to this view. Directors are fiduciaries employed by the shareholders to conduct the business on their behalf. If a board decision protects stakeholder interests by harming those of shareholders, the directors are quite literally stealing from the shareholders:

In a free enterprise, private property system, a corporate executive is an employee of the owners of the business. He has a direct responsibility to his employers. That responsibility is to conduct the business in accordance with their desires, which generally will be to make as much money as possible while conforming to the basic rules of society... Insofar as his actions in accord with his "social responsibility" reduce returns to stockholders, he is spending their money. ${ }^{60}$

\footnotetext{
56 See generally Bainbridge, supra note 47, at 804-11 (discussing the use of workplace democracy arguments in Catholic social teaching).

57 See id. at 785 (arguing that "human dignity is an indeterminate concept requiring greater specification and assessment").

${ }^{58}$ See generally id. at 784-828 (discussing the relationship between hierarchy and human dignity).

59 See generally Stephen M. Bainbridge, Privately Ordered Participatory Management: An Organizational Failures Analysis, 23 DEL. J. CORP. L. 979, 1004-09 (1998) (discussing the economics of hierarchy).

${ }^{60}$ Friedman, supra note 5.
} 
Because private property is such a profound part of the American ethos, this model's ethical implications have strongly influenced U.S. courts and lawmakers. The corporation is a thing, so it can be owned. The shareholders own the corporation, so directors are merely stewards of their interests. ${ }^{61}$ As the Parable of the Talents teaches, stewards are called to faithful service. In particular, as Christ observed in the Sermon on the Mount: "No servant can serve two masters." 62 This observation seems just as valid in economic as in religious life. If so, we cannot expect directors to be simultaneously loyal to the interests of both shareholders and stakeholders. Where those interests conflict, the directors' role as stewards requires them to prefer the interests of their shareholder masters. ${ }^{63}$

This model, however, depends upon the corporation being a thing capable of being owned. It requires one to reify the corporation: to treat the firm as an entity separate from its various constituents. While reification provides a necessary semantic shorthand, taken to extremes it creates a sort of false consciousness. ${ }^{64}$ The corporation is not a thing. It is a legal fiction representing the nexus of the set of contracts among multiple factors of production (a.k.a. corporate constituencies).

b. Contracts and Communities. Hence, when economists (and economically minded legal scholars) look at the corporation, they see a web of contracts. ${ }^{65}$ The Bishops looked at the same firm and saw a community of shared interests. The economist sees inp uts whose team labor produces outputs. ${ }^{66}$ Similarly, the Bishops see workers, creditors, managers, shareholders, and

${ }^{61}$ Cf. Blasius Indus., Inc. v. Atlas Corp., 564 A.2d 651, 663 (Del. Ch. 1988) (opining: "The theory of our corporation law confers power upon directors as the agents of the shareholders ...").

${ }^{62}$ MATTHEW 6:24 (NAB). I acknowledge the irony that the masters of which Christ was speaking at the time were God and money. See id. (stating that one "cannot serve God and mammon").

${ }^{63}$ Cf. Katz v. Oak Indus., Inc., 508 A.2d 873, 879 (Del. Ch. 1986) (holding that a corporation's board is obliged to maximize shareholder interests, even if doing so is adverse to the interests of debenture holders).

${ }^{64}$ On the uses and misuses of reification, see WILLIAM A. KLEIN \& JOHN C. COFFEE, JR., BUSINESS ORGANIZATION AND FINANCE: LEGAL AND ECONOMIC PRINCIPLES 108-09 (7th ed. 2000).

${ }^{65}$ See, e.g., HENRY HANSMANN, THE OWNERSHIP OF ENTERPRISE 18 (1996) (describing the firm as "a nexus of contracts," by which he means that the "firm is in essence the common signatory of a group of contracts" among various factors of production). This model's origins fairly can be traced to Nobel Prize laureate Ronald Coase's justly famous article on the nature of the firm. See R.H. Coase, The Nature of the Firm, 4 ECONOMICA (N.S.) 386 (1937). As no less an authority than former Delaware Chancellor William Allen has acknowledged, contractarianism is now the "dominant legal academic view." William T. Allen, Contracts and Communities in Corporation Law, 50 W ASH. \& LEE L. REV. 1395, 1400 (1993). Contractarianism nevertheless still has critics, including some very distinguished ones. See, e.g., Victor Brudney, Corporate Governance, Agency Costs, and the Rhetoric of Contract, 85 COLUM. L. REV. 1403 (1985); Robert C. Clark, Contracts, Elites, and Traditions in the Making of Corporate Law, 89 COLUM. L. REV. 1703 (1989); Melvin Aron Eisenberg, The Structure of Corporation Law, 89 COLUM. L. RE V. 1461 (1989). For a defense of contractarian theory, see Fred S. McChesney, Economics, Law, and Science in the Corporate Field: A Comment on Eisenberg, 89 COLUM. L. RE V. 1530 (1989).

${ }^{66}$ Building on Coase's work, modern law and economics scholars view the corporation not as an entity but as an aggregate of various inputs acting together to produce goods or services. Employees provide labor. Creditors provide debt capital. Shareholders initially provide equity capital and subsequently bear the risk of losses and monitor the performance of management. Management monitors the performance of employees and coordinates the activities of all the firm's inputs. The firm is the nexus of explicit and implicit contracts establishing rights and obligations among the various inputs making up the firm. See generally Frank H. Easterbrook \& Daniel R. Fischel, The Corporate Contract, 89 COLUM. L. REV. 1416 (1989); Thomas S. Ulen, The Coasean Firm in Law and Economics, 18 J. CORP. L. 301, $318-$ 28 (1993). 
the local communities in which the firm does business as all making a contribution to the firm's success and all having a stake in the enterprise. ${ }^{67}$ The economist sees the directors as coordinating the activities of the other inputs. The Bishops see the directors as the leaders of the community. ${ }^{68}$ The economist sees corporate takeovers as a potential breach of implied contracts between the shareholders and the various other inputs. ${ }^{69}$ The Bishops see them as potential breaches of faith. ${ }^{70}$

At first blush, it may seem that the two are using different language to describe the same phenomenon. On closer examination, however, the Bishops and the economists are talking about two very different things. The economists' contractual understanding of the firm is not communitarian in nature. To the contrary, a common criticism of the contractual model is its incompatibility with the communitarian vision. ${ }^{71}$ As I have explained elsewhere, the contractarian model is perfectly compatible with an understanding of the corporation as a command-and-control hierarchy. ${ }^{72}$

c. The Inaptitude of Communitarianism. According to the Bishops, a community is characterized by reciprocal responsibility. ${ }^{73}$ The Bishops noted, for example, that Israel was commanded to protect those members of the community who were vulnerable to oppression or poverty: widows, orphans, debtors, strangers, and slaves. ${ }^{74}$ They also point out that, in response to Christ's command that we love our neighbors as ourselves, ${ }^{75}$ the early church developed institutional mechanisms to care for those members of their communities who were in need. ${ }^{76}$ Drawing on these examples, the Bishops argue that the members of the corporate community

\footnotetext{
${ }^{67}$ See BISHOPS' LETTER, supra note 7, at 298.

68 See Shaffer, supra note 8, at 329-30. Invocations of the corporation's purported communal character are not uncommon in the business literature. Famed managerialist Peter Drucker, for examples, argues that "the corporation must be organized on hierarchical lines," but at the same time posits that subordinates are just as important to the enterprise's success as their superiors. DRUCKER, supra note 54, at 141. Moreover, he explicitly treats the industrial plant as a "plant community," which not only produces goods, but also should provide essential services to the members of the community. Id. at 191-99.

${ }^{69}$ See, e.g., John C. Coffee, Jr., Shareholders versus Managers: The Strain in the Corporate Web, 85 MICH. L. REV. 1 (1986); Andrei Shleifer \& Lawrence H. Summers, Breach of Trust in Hostile Takeovers, in CORPORATE TAKEOVERS: CAUSES AND CONSEQUENCES 33 (Alan J. Auerbach ed., 1988); but see GREGG, supra note 30, at $42-43$ (criticizing this view).

${ }^{70}$ See BISHOPS' LETTER, supra note 7 , at 9305.

71 See, e.g., Lawrence E. Mitchell, Trust. Contract. Process, in PROGRESSIVE CORPORATE LAW 185, 187 (Lawrence E. Mitchell ed., 1995) (criticizing the "increasing hegemony of contract as the governing model in corporate law"); see also Stephen M. Bainbridge, Community and Statism: A Conservative Contractarian Critique of Progressive Corporate Law Scholarship, 82 CORNELL L. REV. 856, 873-900 (1997) (criticizing left-communitarian theories of the firm).

${ }^{72}$ See Stephen M. Bainbridge, Participatory Management Within a Theory of the Firm, 21 J. CORP. L. 657, 663-64 (1996).

${ }^{73}$ See BISHOPS LETTER, supra note 7, at 936.

${ }^{74}$ See id.; see, e.g., EXODUS 22:21-26; DEUTERONOMY 15:7-18; JEREMIAH 34:8-18.

${ }^{75}$ MARK 12:31.

${ }^{76}$ See BISHOPS LETTER, supra note 7, at $1 \uparrow 51-52$.
} 
have reciprocal moral duties to one another. At the heart of those moral duties is an obligation to treat each member of the community fairly and to respect each member's human dignity. ${ }^{77}$

Communitarian models of the corporation, however, strain credulity past the breaking point. ${ }^{78}$ Roberta Romano aptly observed the inherent linkages between communitarian models and New Left ideology. ${ }^{79}$ Romano explained that this vision is essentially inconsistent with large public corporations:

Adherents of this vision maintain that the decentralization of corporate organizations, involving direct participation in firm decisionmaking by all members, is a prerequisite for establishing fully participatory political structures. For a decentralized communitarian system to work, societal units, being predicated on the economic and political equality of their members, must possess attributes of smallness and sameness. ${ }^{80}$

The public corporation lacks those key attributes. As a left-liberal critic of the communitarian model explained, citing the Bhopal disaster as an example of the problem, communitarians posit that "the retired teacher in California who has invested in Union Carbide through participation in [CalPERS], the factory worker in Pennsylvania, and the relatives of a dead peasant in central India all belong to a single community characterized by ties of mutual interdependence and a history of cooperative activity." fact resembles the nanny state - a large, impersonal bureaucracy better equipped to terrorize than to nurture. As Romano observed, "[communal] characteristics cannot survive within large hierarchical corporations, whose dynamics undermine and destabilize the egalitarian basis of social relationships." 82

${ }^{77}$ See BISHOPS' LETTER, supra note 7, at $\uparrow$ 69; Manuel G. Velasquez, Ethics, Religion and the Modern Business Corporation, in THE CATHOLIC CHALLENGE TO THE AMERICAN ECONOMY: REFLECTIONS ON THE U.S. BSHOPS PASTORAl LETTER ON CATHOLIC SOCIAL TEACHING AND THE U.S. BCONOMY 55, 59-60 (Thomas M. Gannon, S.J., ed., 1987).

${ }^{78}$ See David Millon, Personifying the Corporate Body, 2 GRAVEN IMAGES 116, 127 (1995). To be sure, Catholic neoconservative Michael Novak puts a strongly communitarian gloss on his understanding of the business corporation. See, e.g., NOVAK, supra note 11, at 29; see also GREGG, supra note 30, at 56-57. As we shall see below, communal visions of the corporation become more plausible if we treat the corporation not as a single community, but as a collection of many smaller communities. See infra note 82.

${ }^{79}$ Roberta Romano, Metapolitics and Corporate Law Reform, 36 STAN. L. REV. 923, 948 (1984).

${ }^{80}$ Id. See also infra notes 125-145 and accompanying text (noting and criticizing statist implications of the Bis hops' proposals in this area).

${ }^{81}$ Millon, supra note 78, at 127.

${ }^{82}$ Romano, supra note 79 , at 948 . To be sure, the corporation may harbor within it sub-groups that amount to communities of shared values. The emergence of such sub-group communities is especially likely among those who work for the corporation:

In the economic sphere today sociality seems far more prevalent than individualism. In democratic capitalist nations various social organisms, including the business enterprise and the corporation, have replaced or supplemented old loyalties to family and clan. Some persons today are closer to their colleagues in the workplace than to their family.

NOVAK, supra note 11, at 29. One's co-workers thus provide precisely the cloud of witnesses so essential to the inculcation of virtue. Indeed, one might even argue that communities existing within the corporation help promote religious virtue: "For many millions of religious persons the daily milieu in which they work out their salvation is the communal, corporate world of the workplace." $I d$. at 47. 
Even if we conceded that the corporation is a community, moreover, that community would still face tragic choices. Moral considerations affect hard economic decisions, but cannot eliminate them. Obsolete plants must be closed, even if workers must be laid off. Adverse market conditions may necessitate cuts in pay and/or dividends. To their credit, the Bishops do not ask directors to duck these hard decisions. They do, however, assert that directors, as the corporate community's leaders, must mediate the competing demands of their constituents. ${ }^{83}$ Shareholders benefited from the efforts of the firm's employees, creditors, customers, suppliers, and the communities in which the corporation operated ${ }^{84}$ Shareholder interests alone therefore cannot control. Instead, while directors need not avoid a painful decision, they must consider the decision's impact on everyone who serves the corporation and must strive to minimize its deleterious effects. ${ }^{85}$ But why? And even if the leaders of a community have a moral obligation to balance the interests of every stakeholder in that community when making decisions, should we translate that obligation into the positive law?

\section{PRUDENCE AND THE THORNY PROBLEM OF IMPLEMENTATION}

Suppose society is persuaded by the Bishops. How then would we proceed to operationalize their recommendations? Unfortunately, the Bishops did not address this question, apparently choosing to leave it to policy wonks. In any case, three options suggest themselves. First, we could give directors nonreviewable discretion to make trade-offs between shareholder and stakeholder interests. Second, we could give directors discretion to make such trade-offs subject to some form of judicial review. ${ }^{86}$ Finally, we could mandate that directors make such

To concede Novak's argument for the existence of workplace communities, of course, does not necessitate that we also accept the Bishops' argument for legal change designed to promote their utopian vision of industrial relations. To the contrary, if the corporation harbors within it communities that inculcate virtue in the firm's workers, state interference with the corporation's internal governance becomes indistinguishable from, and hence no less tolerable than, state interference with any other virtue-inculcating institution. Most people belong to a host of communities with the potential to inculcate virtue and other communal values: churches, schools, fraternal organizations, and the like. While it may be unrealistic to think of a large multinational corporation as constituting such a community, it is perfectly plausible to think of the corporation as an intermediary institution standing between the individual and Leviathan. In other words, while virtuous citizens are developed by smaller institutions with roots in the local community, the corporation still can act as a vital countervailing force against the state. Resistance to expanding the realm of mandatory corporate law rules thus responds to the "notion that the prevailing moral threat in our era may not be the power of the corporations, but the growing power and irresponsibility of the state." Id. at 34.

83 Margaret Blair and Lynn Stout have recently advanced what they call a "team production" model of the corporation, which they assert provides an economic rationale for drectors to serve as so-called "mediating hierarchs." See, e.g., Margaret M. Blair \& Lynn A. Stout, A Team Production Theory of Corporate Law, 85 VA. L. REV. 247 (1999); Margaret M. Blair \& Lynn A. Stout, Team Production in Business Organizations: An Introduction, 24 J. CORP. L. 743 (1999). For a response and critique of the mediating hierarch model, see Bainbridge, supra note 4.

${ }^{84}$ See BISHOPS' LETTER, supra note 7, at $\uparrow 305$.

${ }^{85}$ See id.

${ }^{86}$ Some might argue that the Bishops' position already has been operationalized by the so-called nonshareholder constituency statutes adopted by many states (although not Delaware). These statutes give directors discretion (presumably reviewable) to consider the interests of such constituencies when making decisions. Consequently, some scholars argue that these call into question the continuing validity of the shareholder wealth maximization norm. See, e.g., Blair \& Stout, A Team Production Theory of Corporate Law, supra note 83, at 303 n.144; Kent Greenfield \& John E. Nilsson, Gradgrind's Education: Using Dickens and Aristotle to Understand (and Replace?) 
trade-offs subject to judicial review and/or regulatory oversight. Each of these options, however, would leave us worse off than current law.

\section{A. Option A: NONREVIEWABLE Discretion}

It is difficult to think of any socially significant decisionmaker to whom the law gives nonreviewable discretion. ${ }^{87}$ Yet, as a thought experiment, suppose society gave corporate boards of directors the nonreviewable power to consider interests other than shareholder wealth maximization when making decisions. How would boards respond?

An obvious answer is suggested by agency cost economics; namely, the risk of selfdealing. Agency cost economics predicts that directors will not mediate between competing constituencies, but rather use nonshareholder interests to justify decisions that in fact advance their own self-interest. In my view, this is a legitimate concern and, indeed, the strongest objection to the Bishops' proposal. Because a system in which directors are granted reviewable discretion presents the same concern, however, consideration of it may be deferred to the next section.

Hence, suffice it here to suggest that implementing a toothless regime of nonreviewable discretion is unlikely to effect a near-term change in director behavior. Although some scholars claim that directors do not adhere to the shareholder wealth maximization norm, ${ }^{88}$ the weight of the evidence is to the contrary. A 1995 National Association of Corporate Directors (NACD) report stated: "The primary objective of the corporation is to conduct business activities with a view to enhancing corporate profit and shareholder gain." 89 A 1996 NACD report on director professionalism set out the same objective, without any qualifying language on nonshareholder constituencies. ${ }^{90}$ A 1999 Conference Board survey found that directors of U.S. corporations generally define their role as running the company for the benefit of its shareholders. ${ }^{91}$ The 2000

the Business Judgment Rule, 63 BROOKLYN L. REV. 799, 838-39 (1997). As I have argued elsewhere, however, these statutes do not entirely reject the traditional shareholder wealth maximization norm. Instead, they modify the norm by allowing the board to make trade-offs between shareholder and stakeholder interests. See Bainbridge, supra note 35, at 989-96. As such, the statutes admittedly work an unfortunate change in the basic normative principles underlying corporate law. See Stephen M. Bainbridge, In Defense of the Shareholder Wealth Maximization Norm: A Reply to Professor Green, 50 WASH. \& LEE L. REV. 1423, 1423-24 n.2 (1993). Fortunately, courts seem to be ignoring these statutes and, at present, they appear to be little more than dust gathering relics of the $1980 \mathrm{~s}$ wave of state antitakeover legislation. See $i d$. (noting the "dearth of cases"). The nonshareholder constituency statutes were just another exa mple of special interest legislation adopted at the behest of union leaders and managers of target corporations to protect important local businesses from takeovers. Bainbridge, supra note 35, at 993.

${ }^{87}$ Cf. MARY ANN GLENDON, A NATION UNDER LAWYERS 268 (1994) (opining that "the heavy machinery of law is being wheeled out to deal with a growing array of personal, economic, and political matters").

${ }^{88}$ See, e.g., Blair \& Stout, A Team Production Theory of Corporate Law, supra note 83, at 286.

${ }^{89}$ NATIONAL ASSOCIATION OF CORPORATE DIRECTORS, REPORT OF THE NACD BUE RIBBON COMMISSION ON DIRECTOR COMPENSATION: PURPOSES, PRINCIPLES, AND BEST PRACTICES 1 (1995) (noting that "long-term shareholder gain" requires "fair treatment" of nonshareholder constituents).

${ }^{90}$ See NATIONAL ASSOCIATION OF CORPORATE DIRECTORS, REPORT OF THE NACD BLUE RIBBON COMMISSION ON DIRECTOR PROFESSIONALISM 1 (1996).

91 THE CONFERENCE BOARD, DETERMINING BOARD EFFECTIVENESS: A HANDBOOK FOR DIRECTORS AND OFFICERS 7 (1999). 
edition of Korn/Ferry International's well-known director survey found that when making corporate decisions directors consider shareholder interests most frequently, although it also found that a substantial number of directors feel a responsibility towards stakeholders. ${ }^{92}$

What people do arguably matters more than what they say. Director fidelity to shareholder interests has been enhanced in recent years by the market for corporate control and, some say, activism by institutional investors. Hence, for example, the widespread corporate restructurings of the $1990 \mathrm{~s}$ are commonly attributed to director concern for shareholder wealth maximization. ${ }^{93}$ In addition, changes in director compensation have created additional hostages ensuring director fidelity to shareholder interests. ${ }^{94}$ Directors have long given shareholders reputational hostages. If the company fails on their watch, after all, the directors' reputation and thus their future employability is likely to suffer. ${ }^{95}$ In addition, it is becoming common to compensate outside directors in stock rather than cash and to establish minimum stock ownership requirements as a qualification for election. ${ }^{96}$ Tying up the proportion of the director's personal wealth in stock of the corporation creates another hostage, further aligning the director's interests with those of shareholders. ${ }^{97}$

None of this is to say that directors are wholly faithful to shareholder interests. Evidence abounds that when directors have conflicted interests they sometimes (often?) pursue their selfinterest in preference to the interests of either shareholders or any other corporate constituency. My point here is only that, as between shareholder and nonshareholder interests, directors are strongly socialized to put the former first.

\section{B. OPTION B: REVIEWABLE DISCRETION}

Despite the powerful rhetoric of cases like Dodge, current law in fact allows boards of directors substantial discretion to consider the impact of their decisions on interests other than shareholder wealth maximization. This discretion, however, exists not as the outcome of conscious social policy, but rather as an unintended consequence of the business judgment rule. ${ }^{98}$

\footnotetext{
${ }^{92}$ KORN/FERRY INTERNATIONAL, $27^{\text {TH }}$ ANNUAL BOARD OF DIRECTORS ST UDY 33-34 (2000).

93 See, e.g., MiChAEl USEem, INVESTOR CAPITAlism: How MONEy MANAGERS ARE CHANGING THE FACE OF CORPORATE AMERICA 137-67 (1996) (discussing corporate restructurings as a consequence of investor pressure).

${ }^{94}$ Hostages-reciprocal transaction-specific investments-are a central concept in institutional economics. Giving and taking hostages is a mechanism for making credible commitments. I'll pay the ransom, because I know that you will kill the hostage if I do not. See OLIVER E. WLLIAMSON, THE MECHANISMS OF GOVERNANCE 75-78, 124-29 (1996) (discussing the hostage model of contracting).

95 Cf. Eugene F. Fama \& Michael C. Jensen, Separation of Ownership and Control, 26 J. L. \& ECON. 301,315 (1983) (opining that "outside directors will monitor the management that chooses them because outside directors have incentives to develop reputations as experts in decision control").

${ }^{96}$ See generally Charles M. Elson, The Duty of Care, Compensation, and Stock Ownership, 63 U. CIN. L. RE V. 649 (1995) (discussing stock-based director compensation and incentives created thereby).

97 See Outside Directors: The Fading Appeal of the Boardroom, THE ECONOMIST, Feb. 20, 2001, at 67, 69 (relating an anecdote in which one outside director who owned $\$ 500,000$ worth of corporate stock stated: "If this company faces a challenge, I lose sleep at night").

98 The business judgment rule, of course, pervades every aspect of corporate law, from allegedly negligent decisions by directors, to self-dealing transactions, to board decisions to seek dismissal of shareholder litigation, and so on. See, e.g., Sinclair Oil Corp. v. Levien, 280 A.2d 717 (Del. 1971) (discussing fiduciary duties of controlling
} 
Bainbridge: The Bishops and the Corporate Stakeholder Debate

To be sure, some scholars find an inconsistency between the business judgment rule and the shareholder wealth maximization norm. ${ }^{99}$ I concede that the business judgment rule sometimes has the effect of insulating a board of directors from liability when it puts the interests of nonshareholder constituencies ahead of shareholder interests, but deny that that is the rule's intent. ${ }^{100}$ Instead, as the Delaware Supreme Court has explained:

Under Delaware law, the business judgment rule is the offspring of the fundamental principle, codified in [Delaware General Corporation Law] $\S 141(a)$, the business and affairs of a Delaware corporation are managed by or under its board of directors. . . The business judgment rule exists to protect and promote the full and free exercise of the managerial power granted to Delaware directors. ${ }^{101}$

shareholder); Shlensky v. Wrigley, 237 N.E.2d 776 (Ill. App. 1968) (operational decision); Auerbach v. Bennett, 393 N.E.2d 994 (N.Y. 1979) (dismissal of derivative litigation). Two conceptions of the business judgment rule compete in the case law. One treats the rule as having substantive content. In this version, the business judgment rule comes into play only after one has first determined that the directors satisfied some standard of conduct. See, e.g., Cede \& Co. v. Technicolor, Inc., 634 A.2d 345, 360 (Del. 1993) (holding that plaintiffs rebut the business judgment rule's presumption of good faith by "providing evidence that directors, in reaching their challenged decision, breached any one of the triads of their fiduciary duty - good faith, loyalty or due care"). Alternatively, the business judgment rule is seen as an abstention doctrine. Under this version, the court will abstain from reviewing the substantive merits of the directors' conduct unless the plaintiff can rebut the business judgment rule's presumption of good faith. See, e.g., Shlensky, 237 N.E.2d at 779 (holding that "In a purely business corporation ... the authority of the directors in the conduct of the business of the corporation must be regarded as absolute when they act within the law, and the court is without authority to substitute its judgment for that of the directors."). For the reasons developed below, I find the abstention version more persuasive. See infra notes $102-106$ and accompanying text.

99 See Blair \& Stout, A Team Production Theory of Corporate Law, supra note 83, at 303 (arguing that the business judgment rule authorizes directors to make trade-offs between shareholder and nonshareholder interests); Greenfield and Nilsson, supra note 86, at 831 (arguing that the business judgment rule reflects "an underlying distrust of the strict fiduciary duty to maximize shareholder returns"); see also D. Gordon Smith, The Shareholder Primacy Norm, 23 J. CORP. L. 277, 286-87 (1998) (noting that the business judgment rule precludes liability where directors fail to maximize shareholder wealth). In her comments on my paper, Professor Margaret Blair took issue with my interpretation of the relevant precedents. For an argument that Blair has misinterpreted the law in this area, however, see David Millon, New Game Plan or Business as Usual? A Critique of the Team Production Model of Corporate Law, 86 VA. L. REV. 1001, 1009-20 (2000); see also Bainbridge, supra note 4.

${ }^{100}$ To be sure, a few cases can be read to suggest that directors need not treat shareholder wealth maximization as their sole normative objective. Upon close examination, however, most of these cases, in fact, are not inconsistent with the shareholder wealth maximization norm. See supra note 35 (discussing such cases). In Shlensky, 237 N.E.2d 776, for example, a minority shareholder in the Chicago Cubs sued Wrigley, the team's majority shareholder, over the latter's famous refusal to install lights at Wrigley Field. Shlensky claimed the decision against lights was motivated by Wrigley's beliefs that baseball was a day-time sport and that night baseball might have a deteriorating effect on the neighborhood surrounding Wrigley Field. Id. at 778. Despite Shlensky's apparently uncontested evidence that Wrigley was more concerned with nonshareholder than with shareholder interests, the Illinois Appellate Court dismissed for failure to state a claim upon which relief could be granted. Id. at 778-80. Although on superficial examination this result may appear to devalue shareholder wealth maximization, on close examination the case involves nothing more than a wholly unproblematic application of the business judgment rule. See Bainbridge, supra note 35, at 978-79 (discussing Shlensky).

101 Smith v. Van Gorkom, 488 A.2d 858, 872 (Del. 1985). Cf. Marx v. Akers, 666 N.E.2d 1034, 1037 (N.Y. 1996) (noting that "shareholder derivative actions infringe upon the managerial discretion of corporate boards. . . . Consequently, we have historically been reluctant to permit shareholder derivative suits, noting that the power of courts to direct the management of a corporation's affairs should be "exercised with restraint." ); see also Pogostin v. 
The business judgment rule thus operationalizes the intuition that fiat-i.e., centralization of decisionmaking authority - is the essential attribute of efficient corporate governance. ${ }^{102}$ As Nobel laureate economist Kenneth Arrow explains, however, authority and accountability cannot be reconciled:

[Accountability mechanisms] must be capable of correcting errors but should not be such as to destroy the genuine values of authority. Clearly, a sufficiently strict and continuous organ of [accountability] can easily amount to a denial of authority. If every decision of $\mathrm{A}$ is to be reviewed by $\mathrm{B}$, then all we have really is a shift in the locus of authority from $A$ to $\mathrm{B}$ and hence no solution to the original problem. ${ }^{103}$

The business judgment rule prevents such a shift in the locus of decisionmaking authority from boards to judges. It does so by establishing a limited system for case-by-case oversight in which judicial review of the substantive merits of those decisions is avoided. The court begins with a presumption against review. ${ }^{104}$ It then reviews the facts to determine not the quality of the decision, but rather whether the decisionmaking process was tainted by self-dealing and the like. ${ }^{105}$ The questions asked are objective and straightforward: Did the board commit fraud? Did the board commit an illegal act? Did the board self-deal? Whether or not the board exercised reasonable care is irrelevant, as well it should be. ${ }^{106}$ The business judgment rule thus erects a prophylactic barrier by which courts pre-commit to resisting the temptation to review the merits of the board's decision.

The business judgment rule, however, has no application where the board of directors is disabled by conflicted interests. ${ }^{107}$ In such cases, concern for director accountability trumps protection of their discretionary authority. In corporate takeovers, for example, a well-known conflict of interests taints target company director decisionmaking. ${ }^{108}$ Not surprisingly, therefore,

Rice, 480 A.2d 619, 624 (Del. 1984) (noting that "the derivative action impinges on the managerial freedom of directors").

${ }^{102}$ See generally Stephen M. Bainbridge, The Board of Directors as Nexus of Contracts, 88 IOWA L. REV. 1 (2002).

${ }^{103}$ KENNETH J. ARROW, THE LIMITS OF ORGANIZATION 78 (1974).

${ }^{104}$ See, e.g., Aronson v. Lewis, 473 A.2d 805, 812 (Del. 1984) (explaining that the rule creates a presumption that the directors or officers of a corporation acted on an informed basis, in good faith, and in the honest belief that the action taken was in the best interests of the company).

${ }^{105}$ See, e.g., Kamin v. American Express Co., 383 N.Y.S.2d 807, 811 (N.Y. Sup. 1976) (stating that absent "fraud, dishonesty, or nonfeasance," the court would not substitute its judgment for that of the directors).

${ }^{106}$ See, e.g., Joy v. North, 692 F.2d 880, 885 (2d Cir. 1982) ("While it is often stated that corporate directors and officers will be liable for negligence in carrying out their corporate duties, all seem agreed that such a statement is misleading. . . . Whatever the terminology, the fact is that liability is rarely imposed upon corporate directors or officers simply for bad judgment and this reluctance to impose liability for unsuccessful business decisions has been doctrinally labeled the business judgment rule."); Brehm v. Eisner, 746 A.2d 244, 262-64 (Del. 2000) (rejecting plaintiff"s contention that the business judgment rule includes an element of "substantive due care" and holding that the business judgment rule requires only "process due care").

${ }^{107}$ See Bayer v. Beran, 49 N.Y.S.2d 2, 6 (N.Y. Sup. 1944) (explaining: "The 'business judgment rule' . . yields to the rule of undivided loyalty. This great rule of law is designed 'to avoid the possibility of fraud and to avoid the temptation of self-interest."').

${ }^{108}$ Shareholders unquestionably benefit from a successful takeover. Successful bids produce positive abnormal returns for targets ranging from 16.9 percent to 34.1 percent, with a weighted average of 29.1 percent. Moreover, target shareholders appear to capture most of the gains, as abnormal positive returns to bidding firms range from 2.4 
the law denies directors the discretion to consider the interests of nonshareholder constituencies in the takeover setting. ${ }^{109}$ To be sure, the interests of shareholders and nonshareholder may be consistent in takeover fights, just as they are in many settings. In light of the directors' conflict of interests, however, we can no longer trust them to make an unbiased assessment of those competing interests. The conflict between management and shareholder interests requires skepticism when management claims to be acting in the stakeholders' best interests. A board decision to resist a hostile offer may have been motivated by concern for potentially affected nonshareholder constituencies, but it may just as easily have been motivated by the directors' and managers' concern for their own positions and perquisites. Selfish decisions, therefore, easily could be justified by an appropriate paper trail of tears over the employees' fate. Consequently, in the takeover setting, rigorous application of the shareholder wealth maximization norm properly becomes the standard of judicial review.

This then is the major failing of the Bishops' support for a multi-constituency conception of corporate directors' duties. "Any social order that intends to endure must be based on a certain realism about human beings and, therefore, on a theory of sin and a praxis for dealing with it."110 Here, the sin in question is that of self-interest. While the Bishops' proposal would empower honest directors to act in the best interests of all the corporation's constituents, it also would empower dishonest directors to pursue their own self-interest. There is a very real risk that directors and managers given discretion to consider interests other than shareholder wealth maximization will use stakeholder interests as a cloak for actions taken to advance their own selfish interests.

This flaw in the Bishops' analysis is surprising, to say the least. Christianity is not a utopian faith—rather it is quite realistic about human beings. In particular, the central doctrine of the Fall of Man tells a coherent story about the nature and origins of human preferences in an unredeemed world. To be sure, Christians are called to a higher standard of behavior than that of fallen Man. In making social policy, we must remember that all have sinned. ${ }^{111}$ Consider again

percent to 6.7 percent, with a weighted average of 3.8 percent. If a hostile takeover bid fails because of management resistance, the consequences to target company shareholders are thus quite severe. In addition, all shareholders indirectly benefit from takeovers because the disciplining effect of hostile takeovers encourages all corporate managers - not just those fighting off a takeover bid-to maximize shareholder wealth. See Frank A. Easterbrook \& Daniel R. Fischel, Takeover Bids, Defensive Tactics, and Shareholders' Welfare, 36 BUS. LAW. 1733 (1981); Frank A. Easterbrook \& Gregg A. Jarrell, Do Targets Gain From Defeating Tender Offers?, 59 N.Y.U. L. REV. 277 (1984); Gregg A. Jarrell et al., The Market for Corporate Control: The Empirical Evidence Since 1980, 2 J. Econ. Persp. 49 (1988); Michael Jensen \& Richard S. Ruback, The Market for Corporate Control: The Scientific Evidence, 11 J. FIN. ECON. 5 (1983). In contrast, incumbent target managers are the one group unarguably harmed by hostile takeovers. In today's hostile takeover environment, target directors and officers know that a successful bidder is likely to fire many of them. Kenneth J. Martin \& John J. McConnell, Corporate Performance, Corporate Takeovers, and Management Turnover, 46 J. FIN. 671 (1991).

${ }^{109}$ Under the Delaware supreme court's decision in Revlon, Inc. v. MacAndrews \& Forbes Holdings, Inc., a target's board of directors may not protect stakeholder interests at the expense of shareholder interests. $506 \mathrm{~A} .2 \mathrm{~d} 173,182$ (Del. 1986). Rather, any management action benefiting stakeholders must produce ancillary shareholder benefits. $I d$. In addition, once an auction of corporate control begins, stakeholders become entirely irrelevant. In such an auction, shareholder wealth maximization is the board's only appropriate concern. $I d$. Indeed, in this context, considering any factors other than shareholder wealth violates the board's fiduciary duties. $I d$. at 185 .

${ }^{110}$ NOVAK, supra note 11 , at 22.

${ }^{111}$ ROMANS 6:12. 
the Parable of the Talents. The faithless steward put his own self-interest ahead of that of his master, which is precisely what faithless directors might do. ${ }^{112}$

Accordingly, it is consistent with the Christian world view to insist that a realistic social order must be designed around principles that fall short of Christian ideals. In particular, the rules must not be defined in ways that effectively require every citizen to be a practicing Christian. Christian visions of Justice therefore cannot determine the rules of economic order. Instead, legal rules and predictions about human behavior must assume the fallen state of Man. ${ }^{113}$

To be sure, judges could develop standards by which to review the fidelity of fallen directors to multiple constituencies. As one critic of the shareholder wealth maximization norm opines:

[F]iduciaries of various sorts commonly find themselves pulled between competing duties. ... In all these instances, professionals are expected to do the best they can by both developing and working within a framework of reasonable and defensible priorities. Why cannot corporate directors and senior managers be asked to do the same? ${ }^{14}$

He then confidentially predicted that the legal profession will "develop the outlines of a multi-fiduciary" duty after "years of painstaking legal reasoning." 115

But this is more easily said than done. With respect to the ability of directors and managers to juggle the interests of multiple constituencies, consider the Biblical aphorism that no one can serve two masters. ${ }^{116}$ As with the Parable of the Talents, ${ }^{117}$ those of us who find this aphorism theologically sound do so in part precisely because we recognize its validity from our secular experience. ${ }^{118} \mathrm{~A}$ familiar example of a situation in which a fiduciary is "pulled between

\footnotetext{
112 MATTHEW 25:25 (NAB) (recounting how the faithless servant acted to protect himself for fear of the master). For further discussion of the Parable, see supra notes 39-40 and accompanying text.

113 See NovaK, supra note 11, at 28 (observing that no realistic social order can assume "heroic or even consistently virtuous behavior" by its citizens).

114 Ronald M. Green, Shareholders as Stakeholders: Changing Metaphors of Corporate Governance, 50 W ASH. \& LEE L. REV. 1409, 1418 (1993).

${ }^{115}$ Id. at 1419 .

${ }^{116}$ MATTHEW 6:24.

117 In the Parable of the Talents itself, moreover, the faithless steward readily could be held responsible for his defection precisely because the master had a determinate metric of wealth maximization. See MATTHEW 25:30 (NAB) (recounting how the faithless servant was thrown "into the darkness outside, where there will be wailing and grinding of teeth").

${ }^{118}$ Chief Justice Harlan Stone explained that the fiduciary's duty of loyalty was based on:

[T] he precept as old as Holy Writ, that "a man cannot serve two masters." More than a century ago equity gave a hospitable reception to that principle and the common law was not slow to follow in giving it recognition. No thinking man can believe that an economy built upon a business foundation can long endure without loyalty to that principle. . . The separation of ownership from management, the development of the corporate structure so as to vest in small groups control of resources of great numbers of small and uninformed investors, make imperative a fresh and active devotion to that principle if the modern world of business is to perform its proper function.
}

Harlan F. Stone, The Public Influence of the Bar, 48 HARV. L. REV. 1, 8-9 (1934). 
competing duties" is that of the "lawyer for the situation." 119 As anyone who has experience in this area knows, this role is at best uncomfortable and frequently untenable. Consider the example of Louis Brandeis, who coined the phrase:

$[T]$ he greatest caution to be gained from study of the Brandeis record is, never be "counsel for a situation." A lawyer is constantly confronted with conflicts which he is frequently urged to somehow try to work out. I have never attempted this without wishing I had not, and I have given up attempting it. Particularly when old clients are at odds, counsel may feel the most extreme pressure to solve their problems for them. It is a time- consuming, costly, unsuccessful mistake, which usually results in disaffecting both sides. ${ }^{120}$

Even authorities more favorably disposed toward the possibility of attorneys serving as lawyers for the situation acknowledge that that role "is not easy, may fail, and will often bring recrimination in its wake." 121

As for the prospect of developing appropriate standards of review, the "lawyer for the situation" example again proves disquieting. Despite many years of refinement, these rules are still viewed as inadequate, vague, and inconsistent; ${ }^{122}$ hardly the stuff of which certainty and predictability are made. ${ }^{123}$ Yet, despite the central importance of those virtues in corporate law, ${ }^{124}$ this is the sort of model we would end up with if we tried to operationalize the Bishops' position.

In sum, absent the shareholder wealth maximization norm, both boards and courts will lack a determinate metric for assessing options. Instead, stakeholder decisionmaking models inevitably lead to indeterminate results. Worse yet, such models would still lack an adequate praxis for sin. Directors who are responsible to everyone are accountable to no one. Absent clear standards, directors will be tempted to pursue their own self-interest. One may celebrate the virtues of granting directors largely unfettered discretion to manage the business enterprise, without having to ignore the agency costs associated with such discretion. Discretion should not be allowed to camouflage self-interest.

\footnotetext{
${ }^{119}$ See Green, supra note 114, at 1418 (invoking this situation as an example).

${ }^{120}$ John P. Frank, The Legal Ethics of Louis D. Brandeis, 17 STAN. L. REV. 683, 708 (1965).

${ }^{121} 1$ GeOfFREY C. HAZARD, JR. \& W. W ILliaM HODES, THE LAW OF LAWYERING $§ 2.2: 103$, at 513 (2d ed. 1990).

${ }^{122}$ See Marc I. Steinberg \& Timothy U. Sharpe, Attorney Conflicts of Interest: The Need for a Coherent Framework, 66 NOTRE DAME L. REV. 1, 2 (1990); see also Nancy J. Moore, Conflicts of Interest in the Simultaneous Representation of Multiple Clients: A Proposed Solution to the Current Confusion and Controversy, $61 \mathrm{TEX}$ L. REV. 211 (1982).

${ }^{123}$ Cf. Joel C. Dobris, Ethical Problems for Lawyers upon Trust Terminations: Conflicts of Interest, 38 U. MIAMI L. REV. 1, 51 (1983) (observing: "When a person is unhappy about an irrevocable financial arrangement that he has entered into with the participation of a lawyer who also represents another person who is interested in the transaction, there is no certainty or predictability for the lawyer.").

124 See, e.g., Harff v. Kerkorian, 324 A.2d 215, 220 (Del. Ch. 1974) (opining: "It is obviously important that the Delaware corporate law have stability and predictability.").
} 


\section{MaNdATING D IREctor CONSIDERATION OF NONSHAREHOLDER INTERESTS}

In evaluating the final option for operationalizing the Bishops' policy preferences in this area, I hope to be especially provocative. In my view, the Bishops' objections to the shareholder wealth maximization norm are a specific incarnation of the broader attack launched throughout this century against capitalism by a number of prominent Christian scholars and intellectualsi.e., the world view captured by Paul Tillich's claim that "any serious Christian must be a socialist." 125

To be sure, John Paul II's encyclicals make clear that Catholicism decisively rejects socialism in all its forms. ${ }^{126}$ The U.S. Bishops' communitarian model, however, differs from the statism of traditional socialist theory only in degree but not in kind. Instead of supporting direct state regulation of corporate decisionmaking, as old-time socialists urged, the Bishops propose to empower state-sponsored constituency groups (such as labor unions or environmentalists) to exercise some ill-defined degree of influence in corporate decisionmaking processes. ${ }^{127}$ The Bishops thus bring to mind Richard Epstein's trenchant observation that even most socialists no longer advocate direct government ownership of production: "At a personal level, [modern socialism] speaks to the alienation of the individual, stressing the need for caring and sharing and the politics of meaning. At a regulatory level, it seeks to identify specific sectors in which there is a market failure and then to subject them to various forms of government regulation." 128

All of which might be less troubling if the shareholder wealth maximization norm's sole function were to generate profits that in turn serve only, as John Paul II asserted, "as an indicator that a business is functioning well." "129 The corporation's freedom to pursue wealth for its shareholders, however, does more than just expand the economic pie for investors. A legal system that permits pursuit of wealth maximization necessarily must allow individuals freedom to pursue the accumulation of wealth. Economic liberty, in turn, is a necessary concomitant of personal liberty - the two have almost always marched land in hand. ${ }^{130}$ The pursuit of wealth has been a major factor in destroying arbitrary class distinctions, moreover, by enhancing personal and social mobility. ${ }^{131}$ At the same time, the manifest failure of socialist systems to deliver reasonable standards of living has undermined their viability as an alternative to democratic capitalist societies in which wealth maximization is a paramount societal goal.

\footnotetext{
125 RICHARD JOHN NEUHAUS, DOING WELL AND DOING GOOD 47 (1992) (quoting Tillich).

${ }^{126}$ See, e.g., Centesimus Annus, supra note 13, at $\uparrow 13$. 1987).

${ }^{128}$ RICHARD A. EPSTEIN, SIMPLE RULES FOR A COMPLEX W ORLD 23 (1995).

${ }^{129}$ Centesimus Anmus, supra note 13 , at $\uparrow 43$.

${ }^{130}$ See NOVAK, supra note 11 , at 44-45.

${ }^{131}$ See id. at 42 .
}

127 Notably, however, Milton Friedman criticized the BISHOPS" LETTER for finding "the answer to each and every problem in a greater role for government and particularly for central government." Milton Friedman, Good Ends, Bad Means in THE CATHOLIC Challenge TO THE AMERICAN ECONOMY: REFLECTIONS ON THE U.S. BSHOPS' Pastoral Letter on CATHOliC SOCIAL TEACHInG AND THE U.S. EConomy 99, 100 (Thomas M. Gannon ed., 
Accordingly, it seems fair to argue that the economic liberty to pursue wealth is an effective means for achieving a variety of moral ends. ${ }^{132}$

In turn, the modern public corporation has turned out to be a powerful engine for focusing the efforts of individuals to maintain the requisite sphere of economic liberty. As Michael Novak observes, private property and freedom of contract were "indispensable if private business corporations were to come into existence." 133 In turn, the corporation gives "liberty economic substance over and against the state." 134

Those whose livelihood depends on corporate enterprise therefore annot be neutral about political systems. Only democratic capitalist societies permit voluntary formation of private corporations and allot them a sphere of economic liberty within which to function, which gives those who value such enterprises a powerful incentive to resist both statism and socialism. ${ }^{135}$ Because tyranny is far more likely to come from the public sector than the private, those who for selfish reasons strive to maintain both a democratic capitalist society and, of particular relevance to the present argument, a substantial sphere of economic liberty therein serve the public interest. ${ }^{136}$

Concern for human freedom is wholly consistent with Catholic social teaching. As John Paul II explained in Centesimus Annus, socialism was flawed because it maintained "that the good of the individual can be realized without reference to his free choice, to the unique and exclusive responsibility which he exercises in the face of good or evil." "137 Likewise, in Gaudium et Spes, the Second Vatican Council explicitly linked freedom and human dignity. ${ }^{138}$

Subsidiarity is a core principle by which the Church operationalizes its concern for human freedom. The Catechism defines subsidiarity as follows: "A community of a higher order should not interfere in the internal life of a community of a lower order, depriving the latter of its functions, but rather should support it in case of need and help to coordinate its activity with the activities of the rest of society, always with the view to the common good." 139 Hence, Pope Pius $\mathrm{XI}$ explained that "it is an injustice and at the same time a grave evil and disturbance of right

\footnotetext{
${ }^{132}$ See RICHARD A. POSNER, THE PROBLEMS OF JURISPRUDENCE 382 (1990). Professors DeBow and Lee cogently argue that the shareholder wealth maximization norm promotes efficient resource allocation on a society-wide basis, which they plausibly assert redounds to the benefit of consumers - the largest nonshareholder constituency of them all. Michael E. DeBow \& Dwight R. Lee, Shareholders, Nonshareholders and Corporate Law: Communitarianism and Resource Allocation, 18 DEL. J. CORP. L. 393, 416-18 (1993).

${ }^{133}$ NOVAK, supra note 11 , at 45.

${ }^{134} \mathrm{Id}$.

135 See id. at 57.

${ }^{136}$ See id. at 34.

${ }^{137}$ Centesimus Annus, supra note 13, at $\uparrow 13$.

138 Second Vatican Council, Gaudium et Spes q 17, reprinted in PROClAIMING JUSTICE \& PEACE: PAPAL DOCUMENTS FROM RERUM NOVARUMTHROUGH CENTESIMUS ANNUS 157, 169 (Michael Walsh \& Brian Davies eds., 1991).

${ }^{139}$ CATECHISM, supra note 9, at 91883.
} 
order to assign to a greater and higher association what lesser and subordinate organizations can do. $" 140$

[Subsidiarity thus] suggests that people closest to the problem at hand are the ones with the strongest moral claim to finding a solution. To empower higher authorities as anything but second-best solutions or even last resorts endangers the rights and liberties of those who are most affected. The subsidiarity pinciple also embodies the practical point that those closest to the problem have the strongest interest in seeing that the problem is solved most competently. ${ }^{141}$

Subsidiarity does not imply the libertarian's night watchman state excluded from any legitimate role in the economic sphere. ${ }^{142}$ Instead, it implies the need for balance. Paul Johnson observed of capitalism that:

The divine plan was indeed that we should enjoy the fruits of the earth and of our own industry, and capitalism is the best way we have yet devised to organize the latter. But it was equally the divine plan that God should be worshiped and obeyed and, not least, feared. The fear of the Lord, in short, is the beginning of capitalist wisdom, as of any other kind. ${ }^{143}$

Yet, even so, when subordination of economic institutions to the state is viewed from a perspective grounded in the principle of subsidiarity, it must be recognized as posing a grave threat to personal liberty. ${ }^{144}$ Hence, minimizing state regulation of corporate governance is essential to the preservation of a free, yet virtuous society. A limited state is an essential attribute of ordered liberty. In a society premised on the principle of subsidiarity, private property and freedom of contract are important not just in their own right, but ather because they provide essential limitations on the power of the state. As Russell Kirk observed, "freedom and property are closely linked: separate property from private possession, and Leviathan becomes master of all." 145

\section{CONCLUSION}

Edmund Burke contended that individual reason could never fully comprehend the divine intent, although we grope towards it through history, myth, fable, custom, and tradition. ${ }^{146}$ Among these, custom and tradition have special value. They provide a solution for the risk of value disagreement, which modern scholars typically regard as a major problem for natural law-

\footnotetext{
${ }^{140}$ Pius XI, Quadragesimo Anno $\uparrow$ 79, reprinted in PROCLAIMING JUSTICE \& PEACE: PAPAL DOCUMENTS FROM RERUM NOVARUM THROUGH CENTESIMUS ANNUS 41, 63 (Michael Walsh \& Brian Davies eds. 1991).

${ }^{141}$ Robert A. Sirico, Subsidiarity, Society, and Entitlements: Understanding and Application, 11 NOTRE DAME J. L. ETHICS \& PUB. POL'Y 549, 552 (1997).

${ }^{142}$ See, e.g., Centesimus Annus, supra note 13, at $₫ 48$.

${ }^{143}$ Paul Johnson, Blessing Capitalism, COMMENTARY, May 1990, at 33, 36.

144 See, e.g., NOVAK, supra note 11, at 32-34.

${ }^{145}$ RuSSEll KIRK, THE CONSERVATIVE Mind: FrOM BURKE TO ELIOT 9 (7th ed. 1993).

${ }^{146}$ See id. at 50 .
} 
based jurisprudence. ${ }^{147}$ In particular, the customs and traditions of the community provide a standard for identifying universal moral truths that does not require one to accept the claims of any particular faith. Second, respect for tradition is closely linked to the virtue of prudence. Burke echoed Plato in his assertion that prudence was the chief virtue of true statesmen. ${ }^{148}$ When the question of codifying purported natural rights arises, prudence demands that the law of unintended consequences be given its due. The prudent legislator is hesitant to promulgate reforms that may give rise to new and unforeseen abuses worse than the evil to be cured. The prudent legislator therefore respects tradition precisely because the enduring truths of what Burke aptly called "original justice" are revealed slowly, with experience, over time. ${ }^{149}$ The individual is foolish, but the species is wise. We thus turn aside from ancient usage at our peril. $^{150}$

These remarks on the value of prudence are relevant to the topic at hand precisely because the Bishops' comments on the stakeholder debate were prudential rather than magisterial. It is therefore especially appropriate for the laity to evaluate the prudential value of those comments. This article argues that the modern corporation is a vital engine of both economic prosperity and liberty. In turn, the shareholder wealth maximization norm is a central and well-established component of the legal regime within which the corporation has made its valuable social contributions. Prudence dictates continued adherence to that norm. Neither economic democracy nor communitarian ideals justify a moral norm requiring directors to consider the interests of nonshareholder constituencies when making corporate decisions. Instead, as we have seen, modification of the shareholder wealth maximization norm is likely to lead to new abuses in the form of exacerbated agency costs, which would benefit neither shareholders nor stakeholders.

\footnotetext{
147 See, e.g., Philip Soper, Some Natural Confusions about Natural Law, 90 MICH. L. REV. 2393, 2405 (1992) (arguing that: "If we accept that natural law is just another way of claiming that ethical statements can be true or false, then we will have to recognize that people who accept the theory can nevertheless reach different conclusions about fundamental moral questions with no clear way of judging among them.").

${ }^{148}$ See KIRK, supra note 145 , at 22.

149 See Michael W. McConnell, Establishment and Toleration in Edmund Burke's "Constitution of Freedom," 1995 SUP. CT. REV. 393, 403.

${ }^{150}$ See RUSSEll Kirk, THE POLiTiCs OF PRUdenCE 251 (1993).
} 
VILL ANOVA JOURNAL OF LAW AND

INVESTMENT MANAGEMENT

PAGE 28

$*$ 